\title{
Clinicodemographical assessment of colorectal cancer with emphasis on B3GALNT2, MUC1, P53 and Ki67-related risk of metastasis
}

Jalil Mehrzad ( $\nabla$ mehrzad@ut.ac.ir)

University of Tehran https://orcid.org/0000-0001-8174-5431

Ali Ghorbani Ranjbary

Ferdowsi University of Mashhad

Abbas Abdollahi

Mashhad University of Medical Sciences

Saman Hosseinkhani

Tarbiat Modares University Faculty of Biological Sciences

Abbas Tabatabaee

Mashhad University of Medical Sciences

Hesam Dehghani

Ferdowsi University of Mashhad

\section{Research article}

Keywords: B3GALNT2; Colorectal cancer; Ki67; Metastasis; Mucin 1 ; Oncoproteins

Posted Date: September 23rd, 2019

DOI: https://doi.org/10.21203/rs.2.14756/v1

License: (c) (i) This work is licensed under a Creative Commons Attribution 4.0 International License. Read Full License 


\section{Abstract}

Background: The incidence of colorectal cancer (CRC) is rising, worldwide, and is attributed to genetics and epigenetic factors. We aimed to evaluate key demographical/epidemiological/molecular indicators of CRC in CRC patients from a highly populated area in northeastern Iran, retrospective clinical materials-based cohort design and patients were analyzed with respect to age, sex, colorectum anatomy, metastasis, mortality as well as to expression of molecular markers B3GALNT2, mucin I ( MUC1), P53 and Ki67. Methods: Patients, 6260 registered CRC with 3829 underwent surgery, from three medical university hospitals in the study area, during 2006-2016, were analyzed for the clinicodemographic aspects of age, sex, stage of CRC, history of smoking, familial/occupational status and post-surgery survival period as well as mRNA/protein expression of B3GALNT2, MUC1, P53 and Ki67. Factors were set to estimate mortality and risk of metastatic CRC. Results: 75\% of adenocarcinomatous CRC was located in colon, of which younger (with highest risk at transvers colon) and older than 50, was mainly located in rectum and colon, respectively. Post-surgery survival period of metastatic CRC patients was remarkably higher in patients aged $>50$ than those $<50$ years old, and worse in females than males. B3GALNT2 high , MUC1 high , P53 low and Ki67 high mRNA/protein expression in metastatic stage III CRC were highly associated with increased metastasis and mortality. B3GALNT2 high , MUC1 high , P53 low and Ki67 high mRNA/protein expression correlated with increased risk of a progressed CRC state and mortality. The risk to develop metastatic CRC was higher in males, younger individuals, urban residing individuals and employed individuals, indicative of a plausible non-genetics/epigenetics contribution to CRC. Conclusion: The role of possible diagnostic biomarkers, B3GALNT2, MUC1 and Ki67, but not P53, in the etiology/early detection of metastatic CRC is promising. Epigenetic contribution to metastatic $\mathrm{CRC}$ risk is predominant.

\section{Background}

Colorectal cancer (CRC) is normally triggered by the effects of environmental (epigenetic) and genetic factors [1]. The frequency/distribution of age, sex and anatomical sites of cancer in different parts of the colon and rectum differ, which can be attributable to different effects of etiologic factors at the site of CRC. Different molecular/genetic mechanisms are involved in the biological pathway of CRC. In this pathway, the conversion of a normal epithelium to a proliferous one and thus adenoma/adenocarcinoma occure by the DNA methylation-associated mutation in tumor suppressors (e.g. APC, SMAD4, and P53) [2]. Nuclear protein, $\mathrm{P} 53$, is a key pro-apoptotic and anti-proliferative molecule in healthy individuals, and its mutation occurs in various cancer; changes in its mRNA/protein expression is one of the underlying reasons of resistance to chemotherapy [3]. Conversely, the 345-395 kDa Ki67 is an icon for cell proliferation in healthy men/women. The overexpression of Ki67 mRNA/protein has been reported in various tumors [5]. Both P53 and Ki67 are highly expressed in large intestine of CRC patients [4,5].

Mucin 1 (MUC1) is a transmembrane glycoprotein that is over-expressed in various types of human carcinoma, including breast, colon, lung and prostate cancer [6]; it is synthesized as a single polypeptide that undergoes auto-cleavage into MUC1-N and MUC1-C subunits, which form a stable heterodimer at the cell surface [7]. The MUC1-N terminal subunit contains variable numbers of glycosylated tandem repeats [6], 
while the MUC1-C terminal subunit consists of - extracellular, transmembrane and cytoplasmic domains with 58, 28 and 72 amino acids, respectively [8].

As a precursor of mucins family, B3GALNT2 has first been identified as a novel glycosyltransferase having $\beta 1,3-g l y c o s y l t r a n f e r a s e ~ m o t i f s$, which are highly conserved in $\beta 1,3-$ galactosyltranferase and $\beta 1,3-\mathrm{N}$ acetylglucosaminyltranferase families [9]. The purified putative catalytic domain of B3GALNT2 possess of $\mathrm{N}$-Acetylgalactosaminyltransferase activity to form $\beta 1,3$-linkage [7]. Nevertheless, there is little study on the role of B3GALNT2 and related mucin family in metastasis of CRC.

Globally, the woringly rising cancer has claimed millions of lives yearly; though lung cancer claims most lives of all cancers, globally, CRC is nonetheless the second fatal factor in America, while the GIT cancer is considered to emerge as the first with predominantly CRC [10-12], which is considerably demanding critical measures, worldwide. Various studies reveal that about $60 \%$ of the cases with CRC have been detected in developed countries, though early detection/percussion measures have downturned the rate [13]. For example, increased annual colonoscopy checkups for people of both sexes aged 50-75 have substantially prevented the CRC and its annual death rate in the USA [11]. Conversely, annual CRC prevalence/rate and its mortality have been reported to be increasing in developing countries like Iran $[11,14,15]$. To proceed with the current situation in the Middle Eastern countries like Iran regarding the CRC prevalence, it should be noted that the rise in the emergence of cancer, particularly afflicting the patients older or younger than 50 in last 25 years, has alarmingly made this region highly susceptible to cancers, especially CRC $[16,17]$.

Currently, due to the decline in birth rate and the relative life expectancy, the world population is tended towards older. Iran is also experiencing a remarkable change in its age pyramid [18], likely towards older [(i.e., $22 \%$ of the Iranians will be older than 60 by 2050) [19]. So, elder males and females are looming [20].

Due to the huge emergence of CRC and its mortality even in youngers, it is expected that its prevalence turns out to be a challenging dilemma regarding cancer management system in Iran. The present study is concentrated on scrutinizing the CRC patients' medical files classified within the last 10 years, post-surgery survival with some immunohistochemical assays and evaluation of P53, Ki67, B3GALNT2 and MUC1 mRNA/protein expression in (non)metastatic CRC. Here we also aimed to highlight the specific relationship between the changes in age pyramid and the CRC prevalence, the percentage of CRC emergence in various parts of the colorectum, along with determining the efficiency of preventing early CRC.

\section{Methods}

\section{Collection of CRC patient samples}

This study was approved by the ethical committee of Mashhad University of medical science with ID IR.FUBS.REC.1395.42456 with the commitment of the principles of the declaration of Helsinki. As a crosssectional research, the present study was conducted in 3 medical university hospitals (Ghaem, Omid and Imam Reza) in the study area, Mashhad, Iran, during 2006-2016 (Fig. 1), where they received 6260 CRC patients, with 3829 with stages I-IV CRC, undergoing surgery. The details of the selection of patients for the clinicodemographical and molecular analyses are shown as a flow chart (Fig. 2). Retrospectively and prospectively, further clonicoepidemiological along with molecular analyses with medical records (i.e., 
colonoscopy, CT scan, pathology report, anatomical subsites, location/type of CRC/stages and metastasis, age, gender, occupation, familial, place of living, smoking/alcohol/adict and educational status, postsurgery survival in the surgery ward during hospitalization and treatment of the patients) were analyzed $(n=3829)$.

\section{Immunohistochemical and epidemiological trends}

Selected colorectal tissues samples from stages III and IV metastatic CRC patients $(n=315$, age $=30-80$ years) were immunostained with anti-P53 (clone: D0-7), anti-Ki67 (clone: MIB-1) and Anti-Human MUC1 (CD227) antibodies, Clone 214D4 (all with dilution of 1/100 and from Dako, Carpinteria, CA; prediluted) accordingly [20]. Briefly, with EXPOSE human Specific HRP/DAB Detection IHC kit (Abcam, USA) the sections were incubated with the primary antibodies for $60 \mathrm{~min}$, and immunohistochemistry was carried out using biotinylated secondary antibody and streptavidin-alkaline phosphatase conjugate. The antigens were demonstrated by using diaminobenzidine as the chromogen. For negative controls, the primary antiserum step was omitted. All examinations on samples were performed in a blinded manner. The percentage of positively immunostained cells for P53 and Ki67 was counted in 10 different microscopic fields for every section (magnification $\times 400$ ). Results obtained from the image analyzer and software (NIS Elements imaging software (Nikon Instruments NY, Melville, I) were subjected to statistical analyses. Further, the Kaplan-Meier test/estimator was used to estimate the survival rate of the CRC patients.

\section{qPCR assays}

For qPCR assays of P53 and Ki67 mRNA expression, extracted RNA (with kit, Roche Diagnostics, Indianapolis, IN) was purified from metastatic and non-metastatic tissues $(n=60)$ and reverse transcribed for cDNA synthesis kit (Fermentas, Finland), accordingly [21]. Exon junction or intron-spanning primers were designed for 3 pairs of primers (P53, Ki67 and $\beta$-actin, as the reference gene, (designed primer sequences are available upon request). The qPCR conditions for all genes were carried out (in duplicate) with a cycling program including holding for $10 \mathrm{~min}$ at $95^{\circ} \mathrm{C}$, followed by cycling 45 times at $94^{\circ} \mathrm{C}$, annealing temperature of $58^{\circ} \mathrm{C}$, and $72^{\circ} \mathrm{C}$ (20 sec for each temperature), accompanied by melting curve analyses and agarose gel electrophoresis to ascertain the specificity of the reactions or the absence of non-specific PCR products (data not shown). Using GenEX Version 6 software (MultiD, Göteborg, Sweden) and Relative Expression Software Tool (REST; QIAGEN, Hilden, Germany), the normalization and analyses of the qPCR data were calculated according to our previous works [21]. Comparative qPCR results of P53 and Ki67 mRNA expression in metastatic and non-metastatic CRC tissues along with comparison of full heat-map between Ki67 and P53 genes in CRC data were evaluated to see the possible correlation of the mRNA expressions of Ki67 and P53 with CRC metastasis.

Newly designed primers used herein were as follows: MUC1, F: 5'-CCCTATGAGAAGGTTTCTG-3', R: 5'CCTACAAGTTGGCAGAAG-3', B3GALNT2, F: 5'-CCACAGTTTTCTTAGCTC-3', R: 5'- CTCAGTGACATCCTACTC3', P53, F: 5'- CGATGGTGTTACTTCCTGATA-3', R: 5'- CAGCTCTCGGAACATCTC-3', Ki67, F: 5'TCCTTTGGTGGGCACCTAAGACCTG-3', R: 5'- TGATGGTTGAGGTCGTTCCTTGATG-3', $\beta$-actin: F: 5'CTACCTTCAACTCCATCA-3', R: 5'- GAGCAATGTCTTGATCTTC-3'. 


\section{Western blot analysis}

Western blot analysis was performed as previously described [22]. Briefly, large intestinal cancerous and non-cancerous tissues $(0.1 \mathrm{gm})$ were lysed in $0.9 \mathrm{ml}$ lysis buffer [50 mM Tris- $\mathrm{HCl}(\mathrm{pH} 8.0), 150 \mathrm{mM} \mathrm{NaCl}$, $0.5 \%$ Nonidet P-40, $0.5 \%$ CHAPS] including $0.1 \%$ protease inhibitor cocktail III (Calbiochem, San Diego, CA, USA). The tissue lysates were kept on ice for $30 \mathrm{~min}$ and centrifuged at $16000 \times g$ for $10 \mathrm{~min}$ to remove tissue debris. However, its total protein level was measured using bicinchoninic acid assay (BCA) kit (Thermo Scientific). Samples were separated by $12 \%$ sodium dodecyl sulfate polyacrylamide gel electrophoresis (SDS-PAGE) and transferred onto polyvinylidene difluoride membranes (PVDF, Roche, Germany). Membranes were then blocked overnight by $5 \%$ skimmed milk in TBS $0.1 \%$ Tween- 20 , at $4^{\circ} \mathrm{C}$. After incubation of membranes with primary antibody, rabbit anti-human B3GALNT2 pAb (ab228993, Abcam) and anti- $\beta$-actin (AC-15, Sigma-Aldrich, A-5441) at a dilution of 1:1000 and anti-Rabbit HRPconjugated secondary antibody (cell signaling technology, USA) at a dilution of 1:5000; visualization was performed using chemiluminescence-based Clarity Western ECL Substrate (Bio-Rad). Signals on Western blots were quantified by Image J 1.42q software (Wayne Rasband, NIH, Bethesda, MA) and the results were eventually normalized to the B-actin band intensity which was considered as an internal control for loading variations.

\section{Statistical analyses}

The collected data were analyzed via one way $t$ test, ANOVA and Tukey tests. The significance level was 0.05 . All results were presented as mean $\pm S E$. $\chi^{2}$ tests were used to determine the association between P53, Ki67 B3GALNT2 and MUC1 expression with clinicopathological characteristics (especially metastasis), along with analysis of receiver operating characteristics (ROC) [to calculate the predictive values and compare diagnostic efficacy of the studied molecules using the MedCalc statistical program package], whereas the Kaplan-Meier method and log-rank test were used for univariate survival analysis. Also, comparative multivariate ROC analysis with t-test was used to predict any significant relation between P53, Ki67 B3GALNT2 and MUC1 with metastasis. Cox proportional hazards regression was carried out for multivariable survival analysis. Odd ratios (OR) and $99 \%$ confidence intervals $(\mathrm{Cl})$ were obtained. All analyses were carried out using SPSS 17.

\section{Results}

\section{Demographical, anatomical location and histological trends}

Table 1 shows the detailed demographic variables with sample and clinical characteristics of CRC patients at diagnosis stage/site. Of the $6260 \mathrm{CRC}$ registered patients studied during the 11-year period, 3829 underwent surgery (with a mean age of $55.81 \pm 0.003$ years), 1743 were affected by rectum cancer, and 531 were diagnosed with sigmoid cancer. The lowest mean age was in 2014 (52.36 0.003 years).

Of all cases of surgically treated CRC, $61.75 \%$ (2303 cases) were colon cancer, $33.56 \%$ (1255 cases) rectal cancer and $7.26 \%$ (271 cases) rectosigmoid cancer; among those younger than 50, most CRC was in the rectum (Fig. 3). Further, 71.37 \% (2733 cases) and 28.59 \% (1095 cases) were men and women, respectively. 
With minimal and maximal metastatic CRC cases appeared in 2006 and 2013, respectively (Fig. 4E), the most common histological types with the frequencies of $91.53 \%$ and $7.31 \%$, respectively, were adenocarcinoma, not otherwise specified, and mucinous producing adenocarcinoma (Fig. 4). There was a significant relationship between the risk of $\mathrm{CRC}$ and anatomical subsites, where the highest and lowest OR appeared to be the transverse colon $(\mathrm{OR}=1.17,99 \% \mathrm{Cl} 1.44-1.49)$ and sigmoid $(\mathrm{OR}=0.07,99 \% \mathrm{Cl} 1.92-1.94)$ with $\mathrm{P}=0.001$ (Table 1).

\section{Metastasis trends}

Of all cases, $2.84 \%$ (109 cases), $36.04 \%$ (1380 cases), $57.61 \%$ (2206 cases) and $3.49 \%$ (134 cases) related to stages I, II, III and IV, respectively, (Fig. 3A). During the eleven-year of this study, 315 cases of metastatic CRC were registered and metastasis seemed also to be increasing in the region under study over the past 10 years (Fig. 4E). All patients underwent surgery, of which 8.64\% (331 cases) died in hospital after surgery. The overall post-CRC surgery survival period (months) was $42.72 \pm 20.04$ months; post-surgery survival period of metastatic CRC patients younger and older than 50 (Fig. 3C) and female and males (Fig. $3 D$ ), with significantly higher post-CRC surgery survival periods in patients aged $\geq 50$ than those $<50$ years old (Fig. 3C) and in males than females (Fig. 3E).

\section{Immunohistochemical trends}

Of 315 metastatic stage III CRC patients, 218 (69.2\%) and 239 (75.87\%) showed over-expressed and Ki67, B3GALNT2 and MUC1 proteins, but downregulated P53 respectively (see Table 2 and Fig. 4). Further, there was a significantly positive correlation between overexpressed P53 and Ki67 with clinicopathological signs [(specially metastasis in liver (122), lungs (109), omentum (84), bone (58), brain (2) and other organs (8)], though the correlations between over-expressed P53 and Ki67 with age and sex were insignificant (see Table 2). Further, Kaplan-Meier test was used to estimate the survival rate of metastatic CRC patients $(n=315)$ revealed that the post-surgery survival rates in those $<50$ years old $(n=86)$ and $\geq 50(n=229)$ years old were 24 (mean=13.16) months and 24-48 (mean=33.09) months, respectively (Fig. 3E). Significant correlation were observed between the increased $\mathrm{Ki67}(\mathrm{OR}=1.1,99 \% \mathrm{Cl} 1.17-1.30, \mathrm{P}=0.015), \mathrm{P} 53(\mathrm{OR}=1.1,99 \% \mathrm{Cl}$ 1.17-1.30, $P=0.061$ ) and the likelihood of metastastatic CRC (Table 1 and Fig. 5). Figure 5 also shows the percent of metastatic and non-metastatic CRC patients expressing Ki67 (Fig. 5C), with number of those metastatic ( $n=3514)$ and non-metastatic $(n=315)$ CRC patients expressing P53 (Fig. 5B). The protein level of Ki67, but not P53, strongly correlated with metastasis $(P<0.0001)$. MUC1 (with immunohistochemistry) and B3GALNT2 (with Western blot) showed significant overexpression ( $P<0.0001$ and $P=0.0077$, respectively) in metastatic $\mathrm{CRC}$ compared to non-metastatic ones (see Figs $5 \mathrm{D}$ and $5 \mathrm{H}$ ). Figures $5 \mathrm{~B}, 5 \mathrm{C}, 5 \mathrm{D}$ and $5 \mathrm{H}$ show the overall protein expression of P53, Ki67, MUC1, (immunohiatochemistry) and B3GALNT2 (Western blot), respectively. Further, comparative ROC analysis of immunohistochemistry of colorectal tissues in metastasis and non-metastasis CRC P53, Ki67 and MUC1 in metastasis CRC patients and CRC revealed the optimal thresholds for, P53 (AUC = 0.65), Ki67 (AUC = 0.94) and MUC1 (AUC = 0.65) (Fig. 5E-G).

\section{qPCR trends}


Results of globally comparaive qPCR assays on P53 and Ki67 and relaetd heat-map analyses, depicted (Figs 4L and 4M), revealed a strong correlation between the mRNA levels of Ki67, P53, B3GALNT2 and MUC1 and metastasis. mRNA expression of Ki67, B3GALNT2 and MUC1 in stage III CRC patients with metastasis were significantly higher than those without metastasis, (see Figs 5I and 5J) P<0.001). Conversely, the mRNA expression of P53 in stage III CRC patients with metastasis was significantly lower than thos of metastasis $(P<0.01$, Fig. $5 \mathrm{I})$.

\section{Discussion}

Here we reported a survey on $>6000$ CRC patients, but 3829 were being surgically operated, and of these only $~ 10 \%$ were transcriptionally evaluated for well-known key cancer markers, P53 and ki67 along with B3GALNT2 and MUC1, and related clinicodemographic correlation. Though we did not experimentally assess the epigenetic changes, but the clinicodemographic analyses unequivocally exclude genetic contributing factors (i.e., relevant contribution of environmental/non-genetic/epigenetics factors). Based on the results of this study and supported by others, the incidence of CRC is increasing every year, in a way that from 2006 to 2016, a total of 6260 admitted CRC patients two-third of them underwent surgery for affected subsites of colorectum in three specialized hospitals in Mashhad. According to the previous studies in Iran, CRC is the fourth most common cancer in Iranian men after gastric, bladder, and prostate cancers, and the second most common cancer in Iranian women. According to the existing reports, $>4000$ new cases of CRC are diagnosed every year in Iran $[8,19]$. Though the incidence of CRC in Iran is relatively low compared to many countries, it is worryingly increasing [18]. The mortality rate of CRC varies among different racial groups and in various geographical parts, with the lowest incidence in Asia and Africa and the highest in North America and Europe [23]. This is probably due to the predominantly epigenetics/environmental factors, such as stress, low physical activity, life style, age pyramid etc. with lesser extent to genetics $[8,24,25]$. Our study herein showed that the incidence of CRC in men was higher than that of women; this is consistent with the results of others [20]. The mean age of patients with CRC in the study area was 55 years [8], and more serious pattern with rising risk of CRC-related mortality was observed in northwestern neighboring countries [(like Turkey, Armenia...) [26]]. The results of previous studies in Iran and other countries indicate that CRC in men and women are different in each country and region $[8,26,27]$. To our knowledge, it seems likely that deficient in some key trace elements [8] and the microbial flora [28] of the colon at older than 50 could be a significant attributable factor for the development of CRC.

Our results also indicated that the CRC in patients older than 50 occurred in the rectum, and in those aged 20 to 50 it normally occurred in the colon. Consistent with another study [29], the majority of CRC cases (3986 patients, 63.67\%) were related to colon. Also, the incidence of rectum, sigmoid and descending colon cancers were more frequent among men. In line with others [30], cecum, ascending colon and transverse colon (right colon) carcinomas were found to be more prevalent in females. We also found adenocarcinoma (91.53\%) to be the most common pathology followed by mucinosis (7.31\%), which occurred in the second place. This finding is in line with surgery reference books [31]; indeed, $94 \%$ of tumors in the colon are predominantly adenocarcinoma [32,33]. The results of the present study suggest that most patients referred to the hospital were in the stages III and IV CRC post-surgery survival is highly dependent upon the diagnosis 
stage, and typically ranges from a $90 \%$ of 5 -year survival rate for CRCs detected at the localized stage; $70 \%$ for regional to $10 \%$ for people diagnosed for distant metastatic CRC. Indeed, the earlier the stage of diagnosis the higher the chance of survival [34], emphasizing the need to find more definitive oncomarkers for early stage of CRC.

The results here also showed that the survival rates of $1,3,5$ and 10 years old patients were $78.79 \%$, $54.06 \%, 28.4 \%$ and $10.39 \%$, respectively, regardless of others (i.e., gender, education, occupation, clinical features of colorectal cancer before diagnosis, tumor familial, place of residence, smoking, alcohol and addict). This survival rate is lower compared to Europeans and North-Americans, in which delayed detection and lack of follow-up to complete treatment can be attributed to the lower post-surgery survival rate [35]. In line with others' [36], we also found that only age is associated with the survival rate of CRC patients.

Although the prognosis of metastasis and post-surgery relapse in stage III CRC patients is unclear, herein with immunohistochemical-based over-expression of particularly Ki67, MUC1 and overproduction B3GALNT2 proteins (but not P53) along with overexpressed Ki67, MUC1 and B3GALNT2 mRNA (but not P53 mRNA) in metastatic stage III CRC patients and a strong correlation between mRNA of Ki67, MUC1 and B3GALNT2 (but not P53 mRNA) and metastasis we could see promising aspects of these four proteins involved in pathogenesis, prognosis and survival rate of CRC. This result is consistent with others [35,37]. To generate clinically useful molecular guidelines for CRC preventive measures, detection of P53, Ki67, MUC1 and-B3GALNT2 related expressing signals should be precisely implemented.

In this study, $40.97 \%$ of CRC patients ( $94.77 \%$ of the males and $5.22 \%$ of the females) were smokers. However, the relationship between smoking/smoking habits and the incidence of CRC was not confirmed [38]. Similarly, the results of a case study in the US surprisingly showed little relationship between long-term smoking and increased risk of CRC [39]. Nonetheless, smoking is a road for many health issues in today's society.

Mucins have an important function as protective layer for epithelial tissues in the gut and elsewhere in the body. It is well known that during carcinogenesis mucins can be lost or aberrantly expressed in locations where they are not present constitutively. They might be involved in tumor progression and spread. However, the prognostic value of aberrant mucin expression in CRC is controversial [40,41]. Previous publications have reported the impact of MUC1 expression on tumor progression and also on survival [42]. For instance, MUC1 expression has been related to higher TNM stage and reduced recurrence-free and overall survival in 206 patients with CRC [43].

Glycosylation is a post-translational modification and is associated with various physiologic events. In different cancers, the expression of glycosyltransferase in the ER and Golgi apparatus can vary and result in different glycolipid or glycoprotein structures. Polypeptide $\mathrm{N}$ acetylgalactosaminyl transferase (ppGalNAc-T) has been found to be a biomarker and prognostic indicator for breast, gastric and ovarian cancers $[44,45]$. $\mathrm{N}$-acetylglucosamine transferases (GlcNAcT) have been proposed to have a role in invasion or metastasis in gastric and breast cancer as well as serving as biomarkers [46]. Multiple sialyltransferases have been associated with enhanced breast and colorectal cancer with effects on prognostic indicators [47]. 
The aberrant expression of glycosyltransferase and the immature glycan structure of proteins and lipids are observed in many cancers. These phenomena are also involved in the development and progression of cancers $[48,49]$. Abnormalities of the glycan structure and thus oncogenic roles of a cancer-specific glycosyltransferase, UDP-N-acetyl-a-D-galactosamine (GalNAc): polypeptide N-

acetylgalactosaminyltransferase 6 (GALNT6) of glycoproteins are frequently observed in cancer cells [6], regulated cell proliferation and cytoskeleton structure through aberrant O-glycosylation and stabilization of an oncoprotein MUC1 [50].

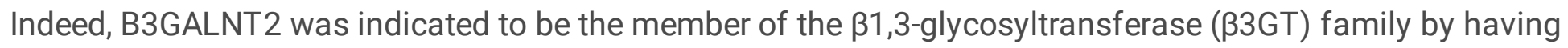
three $\beta 3 G T$ motifs and its function was shown by in vitro analyses to be a synthesis of GalNAc $\beta 1-$ 3 GICNAc $\beta 1-R$ structure on both N-glycans and O-glycans of proteins [51]. However, the biological and biochemical functions of B3GALNT2 have not been clarified in mammalian cells, including human cancer cells, primarily because the GaINAc $\beta 1-3$ GIcNAc $\beta 1-R$ structure has been reported only in a-dystroglycan in mammalian cells [52]. Recently, mutations in the B3GALNT2 gene were identified in individuals with dystroglycanopathy by whole-exome and Sanger sequencing technologies, suggesting that a-dystroglycan is the potential substrate of B3GALNT2 [53].

We examined herein the contribution of P53, Ki67, MUC1 -and B3GALNT2 mRNA to pinpoint the role of examined molecules as biomarkers and also in the biology of the CRC. Since we tested little on those molecules in a healthy population, or in GIT diseased states other than CRC, [i.e., risk factors diseases leading to CRC (e.g., inflammatory bowel disease etc.), it is worth assessing the impacts of P53-and Ki67 on those diseases for further potential clinical value. The observed impact of P53, Ki67, MUC1-and B3GALNT2 mRNA's potentially dynamic effects on cycle/proliferation/spread of large intestinal epithelial cells at the organelle and protein levels might occur [54,55], and could open new doors to understanding the clinicopathological behavior of P53, Ki67, MUC1-and B3GALNT2 molecules as well as the molecular mechanisms that might translate to the body of CRC patients (see schematic Fig. 6). Since mRNA and protein testing of P53, Ki67, MUC1 and B3GALNT2 is not so relevant as expected, it would be worth assessing more samples for more molecules/markers from metastatic tissues at the levels of high throughput protein assays. Although immunohistochemistry and Western blotting is useful assay for assessing on protein level, which gives relevant accumulation of P53, Ki67, MUC1 -and B3GALNT2 proteins following mutations. Nevertheless, immunohistochemistry (which was not done on so many samples herein) and performing additional P53, Ki67, MUC1 -and B3GALNT2 structural and mutational analyses are warranted.

\section{Conclusions}

We reported herein retrospectively on a cohort of 3829 CRC patients in one of the highly populated cities in northeastern Iran underwent surgery along with some clinical and demographic risk factors, and B3GALNT2, MUC1, P53 and Ki67 P53 and Ki-67 immunohistochemistry or Western blot and transcription in 315 of those CRC patients as well. The worrying rise of metastatic CRC incidence in the study area (Iran and Mideastwide), especially in youngers, males, urbans, employed, familial unrelated and transvers colon alarmingly outweights the environmental/epigenetic contribution to CRC risk. Ki67, B3GALNT2 and MUC1, but not P53, 
could be suitable biomarkers for CRC detection, due mainly to correlation of B3GALNT2 ${ }^{\text {high }}$, MUC1 $1^{\text {high }}$ and Ki67 ${ }^{\text {high }}$, mRNA/protein, with CRC metastasis/spread. Nonetheless, the role of possible diagnostic biomarkers, P53 and especially B3GALNT2, MUC1 and Ki67, in the etiology of CRC is promising.

\section{Abbreviations}

B3GALNT2: $\beta$-1,3-N-Acetylgalactosaminyltransferase 2, Cl: Confidence intervals, CL: chemiluminescence, CRC: colorectal cancer, GaINAC: N-Acetylgalactosamine, GALNT6: Polypeptide N Acetylgalactosaminyltransferase 6, GIT: Gastrointestinal tract, G/cNAc: GT O-linked NAcetylglucosaminetransferase, IHC: Immunohistochemistry, Ki-67: Marker of proliferation (MKI) 67protein , MUC1: Mucin 1, OR: Odd ratios, P53:Tumor protein p53, qPCR: quantitative polymerase chain reaction, ROC: Receiver operating characteristic, TNM: tumor-nodes-metastases, WB: Western blotting

\section{Declarations}

\section{Acknowledgments}

The authors appreciate the supports from Ferdowsi University of Mashhad and University of Tehran. We are grateful to Dr. Per Hydbring for critically reading and editing the manuscript.

\section{Authors' contributions}

AGR and JM collected the data, performed the treatments, designed, wrote and finalized the study. JM was also responsible for paper and for its supervision. AA, SH, AT and HD reviewed statistical analyses, supported the data collection and critically revised the manuscript. All authors read and approved the final manuscript.

\section{Funding}

None.

\section{Availability of data and materials}

All data generated or analyzed during this study are included in this published article.

\section{Ethics approval and consent to participate}

This study was approved by the Ethical Committee of Mashhad University of medical science with ID IR.FUBS.REC.1395.42456 with the commitment of the principles of the declaration of Helsinki. All subjects 
signed their informed consents before participation.

\section{Consent for publication}

Not applicable.

\section{Disclosure of interest}

The authors declare that they have no competing interest.

\section{References}

[1] Ranjbary AG, Mehrzad J, Dehghani H, Abdollahi A, Hosseinkhani S.Variation in Blood and Colorectal Epithelia's Key Trace Elements Along with Expression of Mismatch Repair Proteins from Localized and Metastatic Colorectal Cancer Patients, Biol Trace Elem Res. 2019 Jun 6. doi: 10.1007/s12011-019-01749-9..

[2] Willett CG, Chang DT, Czito BG, Meyer J, Wo J. Cancer Genome Atlas Network. Comprehensive molecular characterization of human colon and rectal cancer. Nature 2012.(5). International Journal of Radiation Oncology Biology Physics. 2013; 86(1). https://doi.org/10.1016/j.ijrobp.2012.12.006.

[3] Pietsch EC, Sykes SM, McMahon SB, Murphy ME. The p53 family and programmed cell death. Oncogene 2008;27:6507-6521.

[4] Ma BB, Poon TC, To KF, Zee B, Mo FK, Chan CM, Ho S, Teo PM, Johnson PJ, Chan AT. Prognostic significance of tumor angiogenesis, Ki 67, p53 oncoprotein, epidermal growth factor receptor and HER2 receptor protein expression in undifferentiated nasopharyngeal carcinoma-a prospective study. Head \& Neck 2003;25:864-872.

[5] Wong NA, Mayer NJ, MacKell S, Gilmour HM, Harrison DJ. Immunohistochemical assessment of Ki67 and p53 expression assists the diagnosis and grading of ulcerative colitis-related dysplasia. Histopathol 2000;37:108-114.

[6] Nath S, Mukherjee P. MUC1: a multifaceted oncoprotein with a key role in cancer progression. Trends in molecular medicine. 2014; 20(6):332-42.

[7] Matsuo T, Komatsu M, Yoshimaru T, Kiyotani K, Miyoshi Y, Sasa M, Katagiri T. Involvement of B3GALNT2 overexpression in the cell growth of breast cancer. International journal of oncology. 2014; 44(2):427-34.

[8] Raina D, Agarwal P, Lee J, Bharti A, McKnight CJ, Sharma P, Kharbanda S, Kufe D. Characterization of the MUC1-C cytoplasmic domain as a cancer target. PLoS One. 2015;10(8):e0135156.

[9] Gastinel LN, Bignon C, Misra AK, Hindsgaul O, Shaper JH, Joziasse DH. Bovine a1, 3galactosyltransferase catalytic domain structure and its relationship with $\mathrm{ABO}$ histo-blood group and glycosphingolipid glycosyltransferases. The EMBO journal. 200;20(4):638-49. 
[10] Torre LA, Bray F, Siegel RL, Ferlay J, Lortet-Tieulent J, Jemal A. Global cancer statistics, 2012. CA Cancer J Clin. 2015;65:87-108.

[11] Siegel RL, Miller KD, Jemal A. Cancer statistics, 2016. CA Cancer J Clin 2016; 66:7-30.

[12] Den Uil SH, Coupé VM, Linnekamp JF, Van Den Broek E, Goos JA, Delis-van Diemen PM, Eric J, Van Grieken NC, Scott PM, Vermeulen L, Medema JP. Loss of KCNQ1 expression in stage II and stage III colon cancer is a strong prognostic factor for disease recurrence. Br J Cancer 2016;115:1565-1571.

[13] Mundade R, Imperiale TF, Prabhu L, Loehrer PJ, Lu T. Genetic pathways, prevention, and treatment of sporadic colorectal cancer. Oncoscience. 2014;30:400-406.

[14] Dolatkhah R, Somi MH, Bonyadi MJ, Asvadi Kermani I, Farassati F, Dastgiri S. Colorectal cancer in Iran: molecular epidemiology and screening strategies. J Cancer Epidemiol 2015;643020.

[15] Sparreboom CL, van Groningen JT, Lingsma HF, Wouters MWJM, Menon AG, Kleinrensink GJ, Jeekel J, Lange JF; Different Risk Factors for Early and Late Colorectal Anastomotic Leakage in a Nationwide Audit. Dis Colon Rectum 2018; 61:1258-1266.

[16] Safaee A, Moghimi-Dehkordi B, Fatemi SR, Pourhoseingholi M, Ghiasi S, Zali MR. Colorectal cancer in Iran: an epidemiological study. Asian Pac J Cancer Prev 2008;9:123 -126.

[17] Aimee S J, Veronica R, Jean S W, Enola K, Graham A. Colditz Systems intervention to promote colon cancer screening in safety net settings: protocol for a community-based participatory randomized controlled trial. Implement Sci 2013;8:58-65.

[18] Tanjani PT, Motlagh ME, Nazar MM, Najafi F. The health status of the elderly population of Iran in 2012. Arch Gerontol Geriatr 2015;60:281-287.

[19] Danial Z, Motamedi M, Mirhashemi S, Kazemi A, Mirhashemi AH. Aging in Iran. Lancet 2014;384(9958):1927.

[20] Rafiemanesh H, Pakzad R, Abedi M, Kor Y, Moludi J, Towhidi F, Makhsosi BR, Salehiniya H. Colorectal cancer in Iran: Epidemiology and Morphology Trends. EXCLI J 2016;15:738-744.

[21] Mehrzad J, Bahari A, Bassami MR, Mahmoudi M, Dehghani H. Immunobiologically relevant level of aflatoxin B1 alters transcription of key functional immune genes, phagocytosis and survival of human dendritic cells. Immunol Lett. 2018;197:44-52.

[22] Unver A, Felek S, Paddock CD, Zhi N, Horowitz HW, Wormser GP, Cullman LC, Rikihisa Y. Western blot analysis of sera reactive to human monocytic ehrlichiosis and human granulocytic ehrlichiosis agents. $\mathrm{J}$ Clin Microbiolo. 2001;39(11):3982-6.

[23] Lee KS, Kwak Y, Ahn S, Shin E, Oh HK, Kim DW, Kang SB, Choe G, Kim WH, Lee HS. Prognostic implication of CD274 (PD-L1) protein expression in tumor-infiltrating immune cells for microsatellite 
unstable and stable colorectal cancer. Cancer Immunol Immunother 2017;66:927-239.

[24] Meysamie A, Ghaletaki R, Haghazali M, Asgari F, Rashidi A, Khalilzadeh O, et al. Pattern of tobacco use among the Iranian adult population: results of the national Survey of Risk Factors of Non-Communicable Diseases (SuRFNCD-2007). Tob Control 2010;19:125-128.

[25] Dolatkhah R, Somi MH, Kermani IA, Ghojazadeh M, Jafarabadi MA, Farassati F, Dastgiri S. Increased colorectal cancer incidence in Iran: a systematic review and meta-analysis. BMC Public Health 2015;15:1-14.

[26]Ghoncheh M, Mohammadian M, Mohammadian-Hafshejani A, Salehiniya H. The incidence and mortality of colorectal cancer and its relationship with the human development index in Asia. Ann Glob Health 2016; 82:726-737.

[27]Chen J, Lin Y, Zhang R, Huang ZJ, Pan XG. Contribution of NAD(P)H quinone oxidoreductase 1 (NQ01) Pro187Ser polymorphism and risk of colorectal adenoma and colorectal cancer in Caucasians: a metaanalysis. Arch Med Res 2012;43:55-66.

[28]Sobhani I, Amiot A, Le Baleur Y, Levy M, Auriault ML, Van Nhieu JT, Delchier JC. Microbial dysbiosis and colon carcinogenesis: could colon cancer be considered a bacteria-related disease? Therap Adv Gastroenterol 2013;6(3):215-29.

[29] Siegel R, DeSantis C, Jemal A. Colorectal cancer statistics, 2014. CA Cancer J Clin 2014;64:104-117.

[30] Navabi SJ, Beiranvand B, Pournia Y, Izadi B, Hosseini J, Obeidavi Z, Nasiri B, Rahbar S. Epidemiology of colorectal cancer in patients admitted to Imam Reza hospital in Kermanshah from 2006 to 2011. Basic Clin Cancer Res 2012;27:2-7.

[31] Sabiston D.C, Lyerly H.K. Text book of surgery 16th ed .Philadelphia. W. B Saunders Co. 2001;961-969.

[32] Mansori K, Solaymani-Dodaran M, Mosavi-Jarrahi A, Motlagh AG, Salehi M, Delavari A, Asadi-Lari M. Spatial Inequalities in the Incidence of Colorectal Cancer and Associated Factors in the Neighborhoods of Tehran, Iran: Bayesian Spatial Models. J Prev Med Public Health 2018;51:33-36.

[33] Shadmani FK, Ayubi E, Khazaei S, Sani M, Hanis SM, Khazaei S, Soheylizad M, Mansori K. Geographic distribution of the incidence of colorectal cancer in Iran: a population-based study. Epidemiol and Health 2017;17: 1-13.

[34] Haggar FA, Boushey RP. Colorectal cancer epidemiology: incidence, mortality, survival, and risk factors. Clin Colon Rectal Surg 2009;22:191-197.

[35] Hoseini S, Moaddabshoar L, Hemati S, Mohammadianpanah M. An overview of clinical and pathological characteristics and survival rate of colorectal cancer in Iran. Ann colorectal Res 2014;2:e17264.

[36]Yoosefi M, Baghestani AR, Khadembashi N, Pourhoseingholi MA, Baghban AA, Khosrovirad A. Survival Analysis of Colorectal Cancer Patients Using Exponentiated Weibull Distribution. Int J Cancer Management 
[37] Wang L, Liu Z, Fisher KW, Ren F, Lv J, Davidson DD, Baldridge LA, Du X, Cheng L. Prognostic value of programmed death ligand 1, p53, and Ki-67 in patients with advanced-stage colorectal cancer. Hum Pathol 2018;71:20-29.

[38] Limsui D, Vierkant RA, Tillmans LS, Wang AH, Weisenberger DJ, Laird PW, Lynch CF, Anderson KE, French AJ, Haile RW, Harnack LJ. Cigarette smoking and colorectal cancer risk by molecularly defined subtypes. J Natl Cancer Inst 2010;102:1012-1022.

[39] Peppone LJ, Hyland A, Moysich KB, Reid ME, Piazza KM, Purnell JQ, Mustian KM, Morrow GR. Examining the association between cigarette smoking and colorectal cancer using historical case-control data. Cancer Epidemiol 2009;33:182-188.

[40] Byrd JC, Bresalier RS. Mucins and mucin binding proteins in colorectal cancer. Cancer Metast Rev. 2004;23:77-99.

[41] Bu X-D, Li N, Tian X-Q, Li Li, Jin-Song Wang, Xiao-Jin Yu, and Pei-Lin Huang. Altered expression of MUC2 and MUC5AC in progression of colorectal carcinoma. World J Gastroenterol. 2010;16:4089-4094.

[42] Jing X, Liang H, Hao C, Yang X, Cui X. Overexpression of MUC1 predicts poor prognosis in patients with breast cancer. Oncol Rep. 2019;41(2):801-10.

[43] Khanh DT, Mekata E, Mukaisho K-I, et al. Transmembrane mucin MUC1 overexpression and its association with $\mathrm{CD} 10^{+}$myeloid cells, transforming growth factor- $\beta 1$ expression, and tumor budding grade in colorectal cancer. Cancer Sci. 2013;104:958-964.

[44] Almaraz RT, Tian Y, Bhattarcharya R, Tan E, Chen SH, Dallas MR, Chen L, Zhang Z, Zhang H, Konstantopoulos K, Yarema KJ. Metabolic flux increases glycoprotein sialylation: implications for cell adhesion and cancer metastasis. Mol Cell Proteomics. 2012;11(7):M112 017558.

[45] Ju T, Aryal RP, Kudelka MR, Wang Y, Cummings RD. The Cosmc connection to the Tn antigen in cancer. Cancer Biomark. 2014;14(1):63-81.

[46] Peixoto A, Relvas-Santos M, Azevedo R, Santos LL, Ferreira JA. Protein glycosylation and tumour microenvironment alterations driving cancer hallmarks. Front Oncol. 2019;9:380.

[47] Ogawa T, Hirohashi Y, Murai A, Nishidate T, Okita K, Wang L, Ikehara Y, Satoyoshi T, Usui A, Kubo T, Nakastugawa M. ST6GALNAC1 plays important roles in enhancing cancer stem phenotypes of colorectal cancer via the Akt pathway. Oncotarget. 2017;8(68):112550.

[48] Nath S, Mukherjee P. MUC1: a multifaceted oncoprotein with a key role in cancer progression. Trends Mol Med. 2014;20:332-42. 
[49] Hu M, Lan Y, Lu A, Ma X, Zhang L. Glycan-based biomarkers for diagnosis of cancers and other diseases: Past, present, and future. Prog Mol Biol TransI Sci. 2019;162:1-24.

[50] Park JH, Katagiri T, Chung S, Kijima K, Nakamura Y. Polypeptide N-acetylgalactosaminyltransferase 6 disrupts mammary acinar morphogenesis through 0-glycosylation of fibronectin. Neoplasia (New York, NY). 2011;13(4):320.

[51] Hiruma T, Togayachi A, Okamura K, Sato T, Kikuchi N, Kwon YD, Nakamura A, Fujimura K, Gotoh M, Tachibana K, Ishizuka Y. A novel human $\beta 1$, 3-N-acetylgalactosaminyltransferase that synthesizes a unique carbohydrate structure, GalNAcß1-3GIcNAc. J Biol Chem. 2004;279(14):14087-95.

[52] Matsuo T, Komatsu M, Yoshimaru T, Kiyotani K, Miyoshi Y, Sasa M, Katagiri T. Involvement of B3GALNT2 overexpression in the cell growth of breast cancer. Int J Oncol. 2014;44(2):427-34.

[53] Johnson K, Bertoli M, Phillips L, Töpf A, Van den Bergh P, Vissing J, Witting N, Nafissi S, Jamal-Omidi S, Łusakowska A, Kostera-Pruszczyk A. Detection of variants in dystroglycanopathy-associated genes through the application of targeted whole-exome sequencing analysis to a large cohort of patients with unexplained limb-girdle muscle weakness. Skeletal Muscle. 2018;8(1):23.

[54] Sysel AM, Valli VE, Bauer JA. Immunohistochemical quantification of the cobalamin transport protein, cell surface receptor and $\mathrm{Ki}-67$ in naturally occurring canine and feline malignant tumors and in adjacent normal tissues. Oncotarget. 2015;6(4):2331.

[55] Yuan JP, Wang LW, Qu AP, Chen JM, Xiang QM, Chen C, Sun SR, Pang DW, Liu J, Li Y. Quantum dotsbased quantitative and in situ multiple imaging on ki67 and cytokeratin to improve ki67 assessment in breast cancer. PloS One. 2015;10(4):e0122734.

\section{Tables}

Table 1 Cox proportional hazards analyses in relation to overall demographic and risk variables, sam] characteristics, various levels of participants and clinical characteristics of CRC patients/participants at diagno stage/site $(\mathrm{n}=3829)$. 
Variable

\begin{tabular}{|c|c|c|c|c|c|}
\hline Variable & Parameters & Rate (\%) & UR & $99 \%$ CI & p-value \\
\hline Age group & $\begin{array}{l}\geq 50 \text { years } \\
<50 \text { years }\end{array}$ & $\begin{array}{l}2839 \\
(74.14) \\
990 \\
(25.85)\end{array}$ & $\begin{array}{l}2.8 \\
0.34\end{array}$ & $\begin{array}{l}1.24- \\
1.28 \\
1.73- \\
1.77\end{array}$ & $\begin{array}{l}< \\
0.0001\end{array}$ \\
\hline Education & $\begin{array}{l}\text { Illiterate } \\
\text { Diploma } \\
\text { Academic }\end{array}$ & $\begin{array}{l}1015(35) \\
1593 \\
(37.5) \\
1221 \\
(27.5)\end{array}$ & $\begin{array}{l}0.36 \\
0.56 \\
0.54\end{array}$ & $\begin{array}{l}1.69- \\
1.73 \\
1.56- \\
1.60 \\
1.66- \\
1.70 \\
\end{array}$ & $\begin{array}{l}< \\
0.0001\end{array}$ \\
\hline Gender & 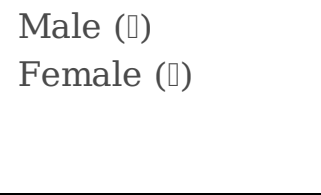 & $\begin{array}{l}2733 \\
(57.5) \\
1096 \\
(42.5)\end{array}$ & $\begin{array}{l}2.4 \\
0.4\end{array}$ & $\begin{array}{l}1.27- \\
1.31 \\
1.69- \\
1.73\end{array}$ & 0.0001 \\
\hline Job & $\begin{array}{l}\text { Unemployed } \\
\text { Employed }\end{array}$ & $\begin{array}{l}930(27.5) \\
2899 \\
(72.5)\end{array}$ & $\begin{array}{l}0.3 \\
3.1\end{array}$ & $\begin{array}{l}1.71- \\
1.75 \\
1.25- \\
1.29\end{array}$ & $\begin{array}{l}< \\
0.0001\end{array}$ \\
\hline Tumor location & $\begin{array}{l}\text { Ascending colon } \\
\text { Descending colon } \\
\text { Transverse colon } \\
\text { Rectum } \\
\text { Sigmoid }\end{array}$ & $\begin{array}{l}559 \\
(15.64) \\
364(9.5) \\
2068 \\
(54.5) \\
1255 \\
(33.65) \\
271(7.26)\end{array}$ & $\begin{array}{l}0.17 \\
0.11 \\
1.17 \\
0.48 \\
0.07\end{array}$ & $\begin{array}{l}1.84- \\
1.87 \\
1.89- \\
1.92 \\
1.44- \\
1.49 \\
1.65- \\
1.69 \\
1.92- \\
1.94 \\
\end{array}$ & 0.001 \\
\hline Metastasis & $\begin{array}{l}\text { Ki67 high } \\
\text { Ki67low } \\
\text { P53 }^{+} \\
\text {P53- }^{-}\end{array}$ & $\begin{array}{l}239 \\
76 \\
218 \\
97\end{array}$ & $\begin{array}{l}1.1 \\
0.004 \\
1 \\
0.005\end{array}$ & $\begin{array}{l}1.17- \\
1.30 \\
1.69- \\
1.82 \\
1.24- \\
1.37 \\
1.62- \\
1.75\end{array}$ & $\begin{array}{l}0.0015 \\
0.0061\end{array}$ \\
\hline Tumor familiar & $\begin{array}{l}\text { Yes } \\
\text { No }\end{array}$ & $\begin{array}{l}102(2) \\
3727(98)\end{array}$ & $\begin{array}{l}0.02 \\
3.7\end{array}$ & $\begin{array}{l}1.97- \\
1.98 \\
1.07- \\
1.09\end{array}$ & $\begin{array}{l}< \\
0.0001\end{array}$ \\
\hline Place of residence & $\begin{array}{l}\text { Urban } \\
\text { Rural }\end{array}$ & $\begin{array}{l}2963 \\
(77.3) \\
866(22.6)\end{array}$ & $\begin{array}{l}3.4 \\
0.2\end{array}$ & $\begin{array}{l}1.21- \\
1.24 \\
1.76- \\
1.79 \\
\end{array}$ & 0.02 \\
\hline $\begin{array}{l}\text { Clinical features of colorectal cancer before } \\
\text { diagnosis }\end{array}$ & $\begin{array}{l}\text { Constipation } \\
\text { Colonoscopy } \\
\text { Diarrhea } \\
\text { Abdominal pain } \\
\text { Rectal bleeding } \\
\text { Weight loss }\end{array}$ & $\begin{array}{l}1100 \\
(28.7) \\
809(21.1) \\
985(25.7) \\
2097 \\
(54.7)\end{array}$ & $\begin{array}{l}0.41 \\
0.26 \\
0.32 \\
1.2 \\
0.26 \\
0.02\end{array}$ & $\begin{array}{l}1.69- \\
1.73 \\
1.77- \\
1.81 \\
1.72- \\
1.76\end{array}$ & $\begin{array}{l} \\
\\
< \\
0.0001\end{array}$ \\
\hline
\end{tabular}




\begin{tabular}{|c|c|c|c|c|c|}
\hline & $\begin{array}{l}\quad \text { Abnormal rectal } \\
\quad \text { examination } \\
\text { Anemia } \\
\text { Nausea and Vomiting } \\
\text { Weakness }\end{array}$ & $\begin{array}{l}799(20.8) \\
102(2.6) \\
1201 \\
(31.3) \\
637(16.6) \\
310(8) \\
254(6.6)\end{array}$ & $\begin{array}{l}0.45 \\
0.2 \\
0.08 \\
0.07\end{array}$ & $\begin{array}{l}1.43- \\
1.47 \\
1.77- \\
1.81 \\
1.97- \\
1.98 \\
1.67- \\
1.71 \\
1.82- \\
1.85 \\
1.91- \\
1.93 \\
1.92- \\
1.94\end{array}$ & \\
\hline Smoking, alcohol and addict & $\begin{array}{l}\text { Smoking } \\
\text { Alcohol } \\
\text { Addict }\end{array}$ & $\begin{array}{l}1111(29) \\
450(11.7) \\
213(5.5)\end{array}$ & $\begin{array}{l}0.4 \\
0.16 \\
0.05\end{array}$ & $\begin{array}{l}1.72- \\
175 \\
1.84- \\
1.87 \\
1.93- \\
1.95\end{array}$ & $\begin{array}{l}< \\
0.0001\end{array}$ \\
\hline
\end{tabular}

Table 2 Chi- $\chi \square$ analyses in relation to correlation of P53 and Ki67 expression with clinicopathologic features in metastatic colorectal cancer $(\mathrm{CRC}, \mathrm{n}=315) . \chi \square$ is the relation between oncoprotein's expression and clinocopathological features (when $\chi \square \leq 0.5$ is significant).

\begin{tabular}{|c|c|c|c|c|c|c|c|}
\hline Clinicopathologic features & $\mathrm{n}$ & $\mathrm{P} 3^{+}(\%)$ & P53- (\%) & $\chi^{\square} P$-value & Ki67 ${ }^{\text {high }}(\%)$ & Ki67'low (\%) & $\chi \square P$-value \\
\hline $\begin{array}{l}\text { Age } \square \text { years } \square \\
\leq 50 \\
\geq 50\end{array}$ & $\begin{array}{l}195 \\
120 \\
\end{array}$ & $\begin{array}{l}141(72.3) \\
77(64.16)\end{array}$ & $\begin{array}{l}54(27.7) \\
43(35.84)\end{array}$ & 0.85 & $\begin{array}{l}153(78.46) \\
86(71.66)\end{array}$ & $\begin{array}{l}43(21.54) \\
33(28.34)\end{array}$ & 0.719 \\
\hline $\begin{array}{l}\text { Gender } \\
\square \\
\square\end{array}$ & $\begin{array}{l}219 \\
96 \\
\end{array}$ & $\begin{array}{l}179(81.73) \\
39(40.62) \\
\end{array}$ & $\begin{array}{l}40(18.27) \\
57(59.38) \\
\end{array}$ & 0.99 & $\begin{array}{l}184(84) \\
55(57.29) \\
\end{array}$ & $\begin{array}{l}35(16) \\
41(42.71) \\
\end{array}$ & 0.852 \\
\hline $\begin{array}{l}\text { Location } \\
\text { Colon } \\
\text { Rectum } \\
\text { Sigmoid } \\
\end{array}$ & $\begin{array}{l}284 \\
28 \\
3 \\
\end{array}$ & $\begin{array}{l}198(69.71) \\
18(64.28) \\
2(66.66) \\
\end{array}$ & $\begin{array}{l}86(30.29) \\
10(35.72) \\
1(33.34) \\
\end{array}$ & $0.108^{*}$ & $\begin{array}{l}217(76.4) \\
20(71.42) \\
2(66.66) \\
\end{array}$ & $\begin{array}{l}67(23.6) \\
8(28.58) \\
1(33.34) \\
\end{array}$ & $0.137 *$ \\
\hline Total Metastasis & 315 & $218(69.2)$ & $97(30.8)$ & & $239(75.87)$ & $76(24.13)$ & \\
\hline
\end{tabular}

\section{Figures}




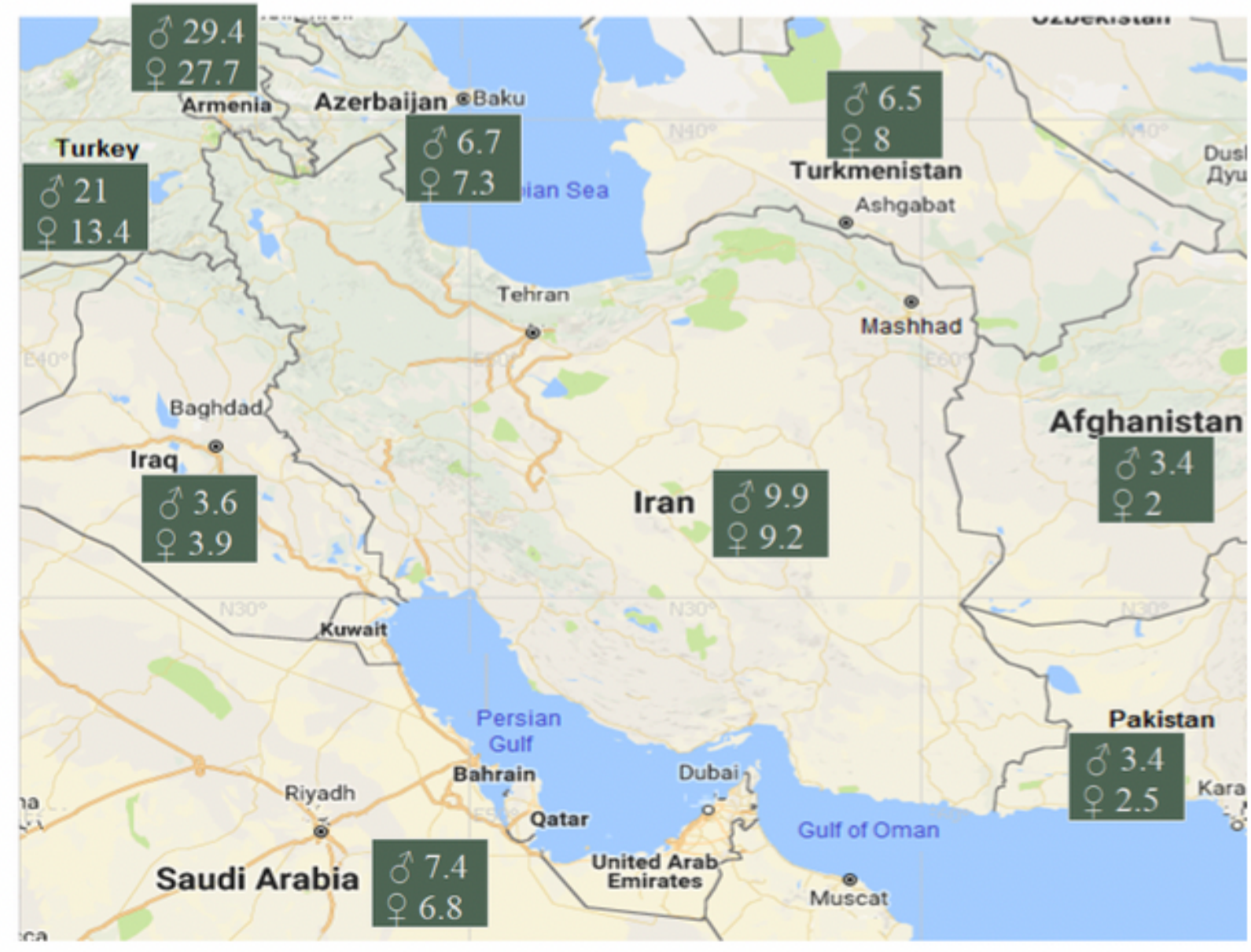

Figure 1

The study area (Northeastern Iran with comparative countrywide information related to colorectal cancer

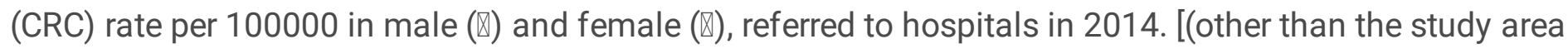
are referred to (26)]. 


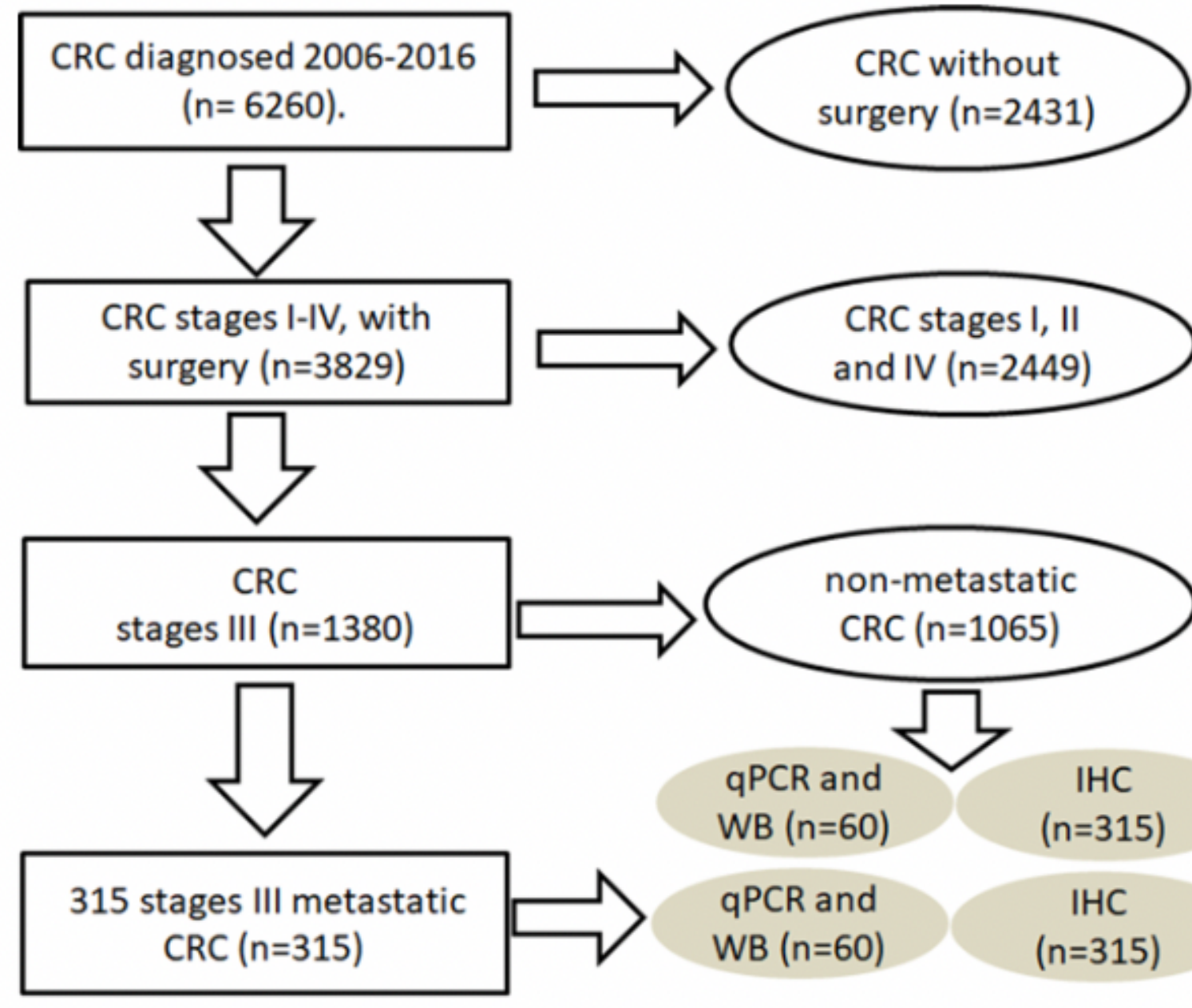

Figure 2

Flow chart depicting the selection of patients. 


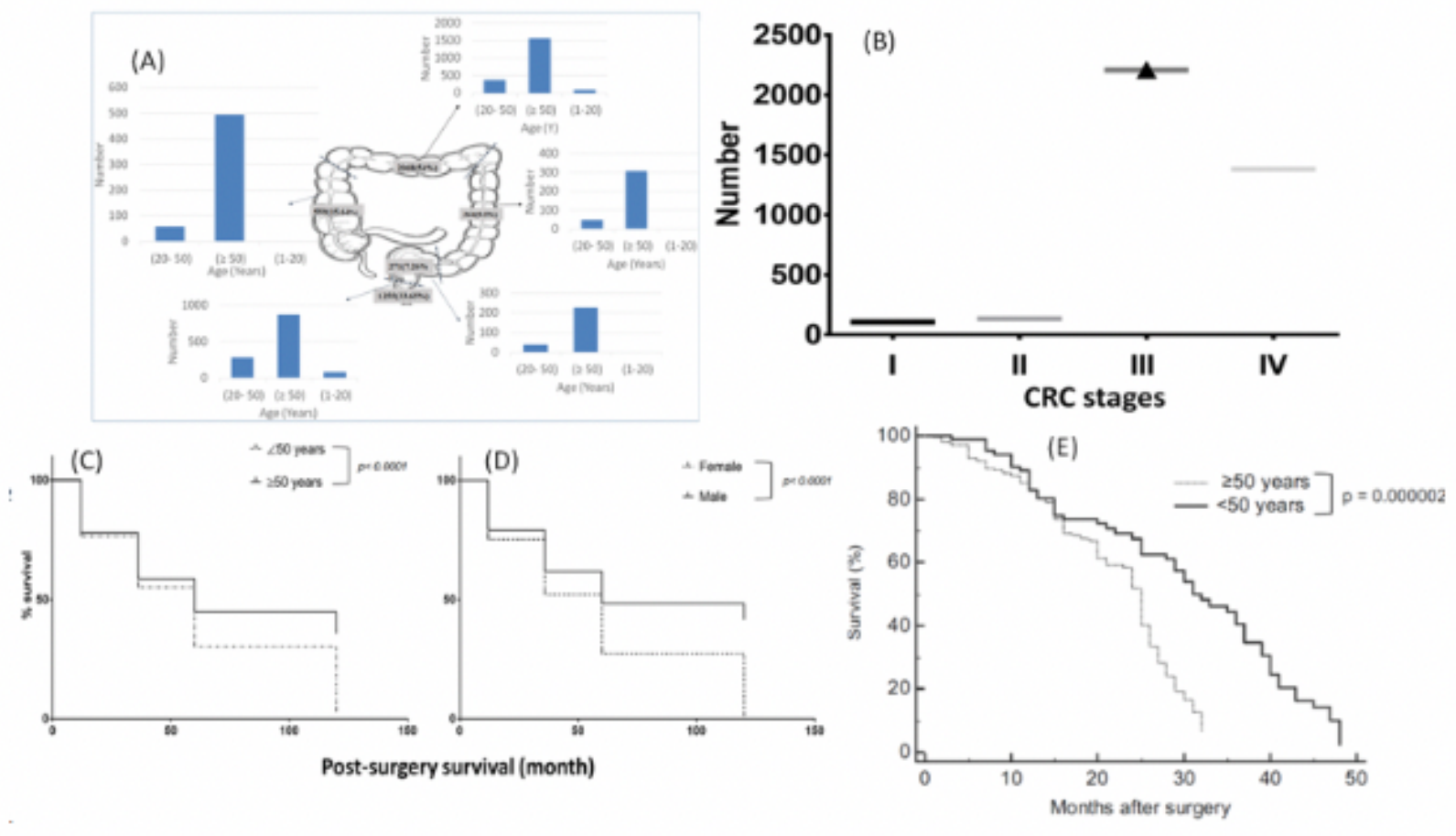

Figure 3

Distribution of various subsites of colorectum with relation to the age affected by CRC observed in Mashhad, Iran, 2006-2016 (A). Number of colorectal cancer (CRC) patients with different stages of CRC (B). Results of Kaplan-Meier test to estimate the survival rate of the metastatic CRC patients ( $n=315$, of which $n=86<50$ and $n=229 \geq 50$ ) and $p$-value was calculated through a log rank test (C). Post-surgery survival period (months) of metastatic CRC patients males ( $n=2733,57.5 \%)$ and females ( $n=1096,42.5 \%)$, (D) and younger $(n=990,28.85 \%)$ and older $(n=2839,74.14 \%)$ than $50(E)$.
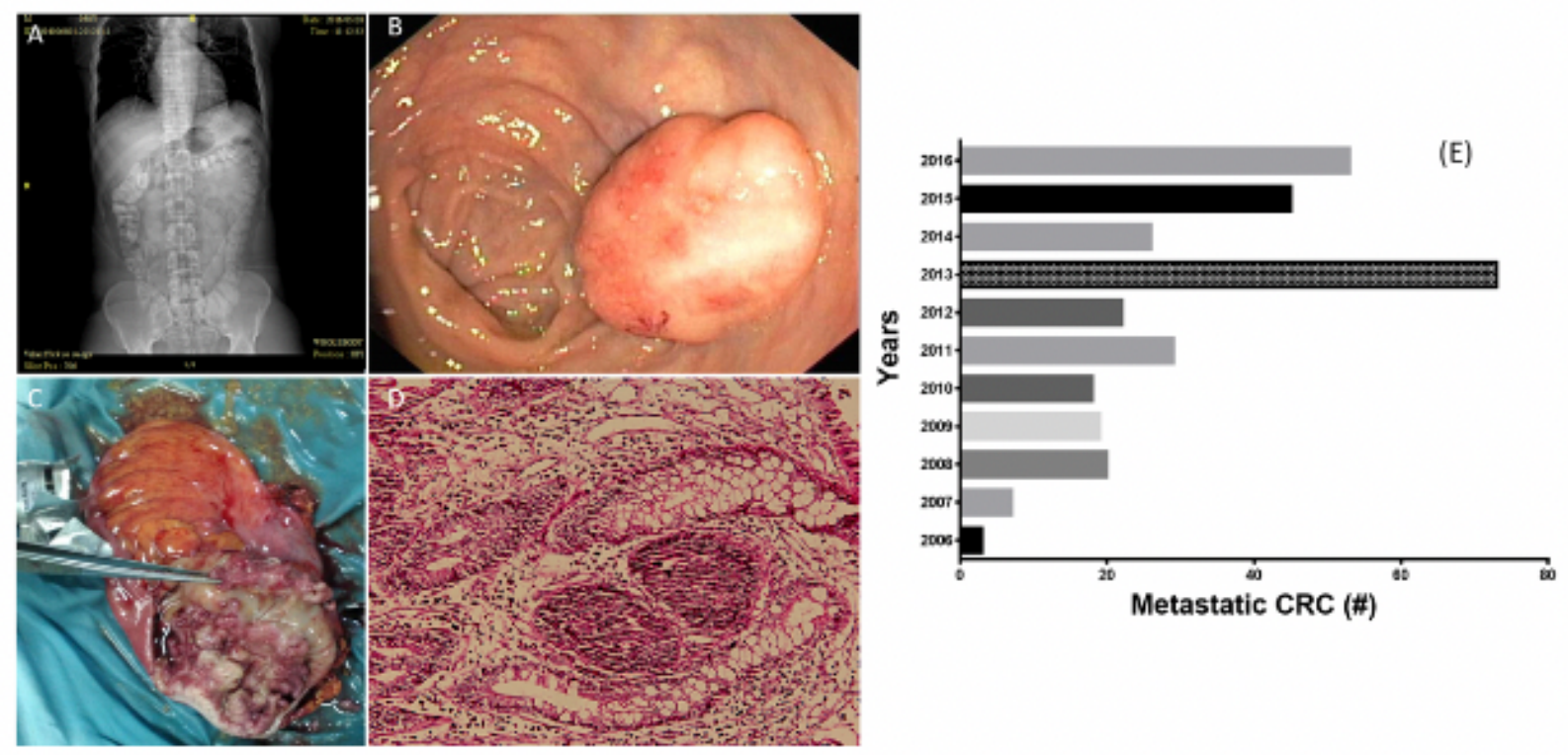

Figure 4 
Subjects in the staging category of colorectal cancer (CRC). A) CT scan, B) removed cancerous parts of descending colon, C) colonoscopy of cancerous part of descending colon and D) adenocarcinoma, a predominant form of CRC $(H \& E, \times 100)$. Differences between the number of metastatic CRC patients during the cross-sectional retrospective study period, with maximal metastasis in $2013(E)$.
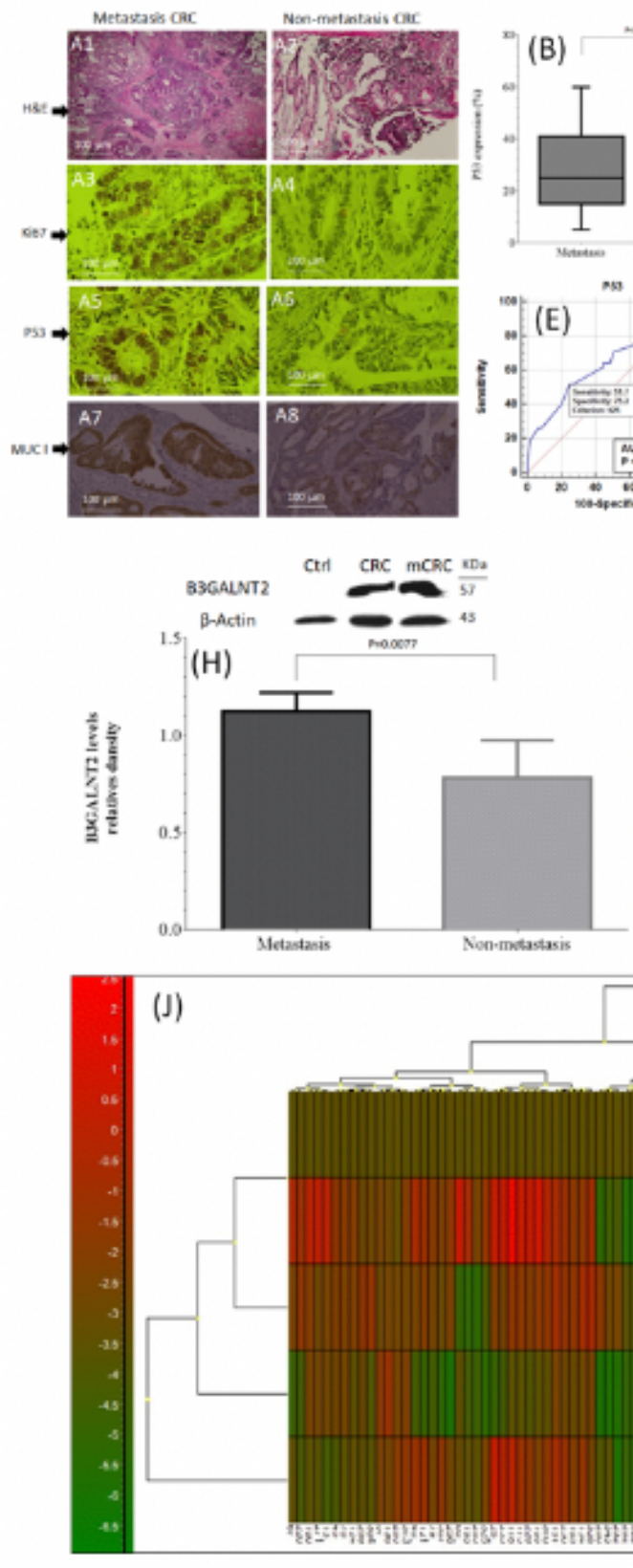
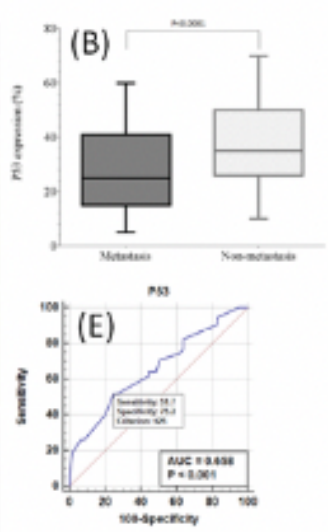
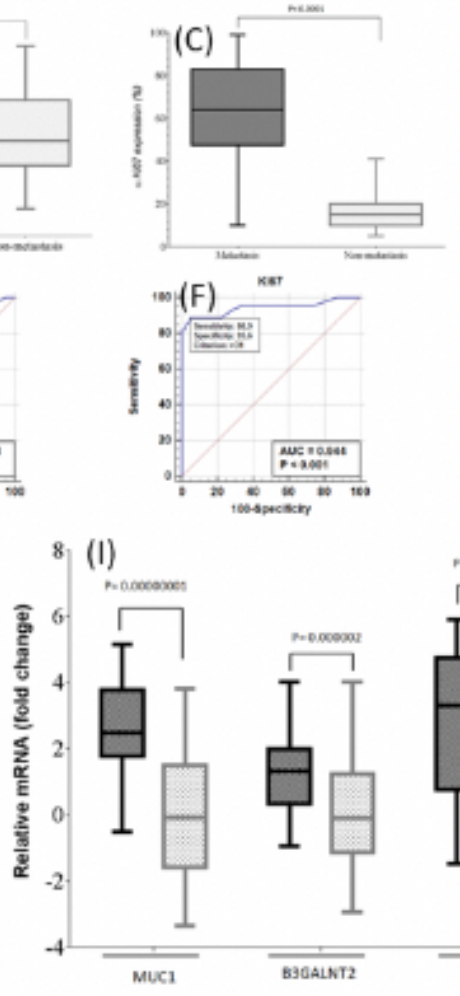
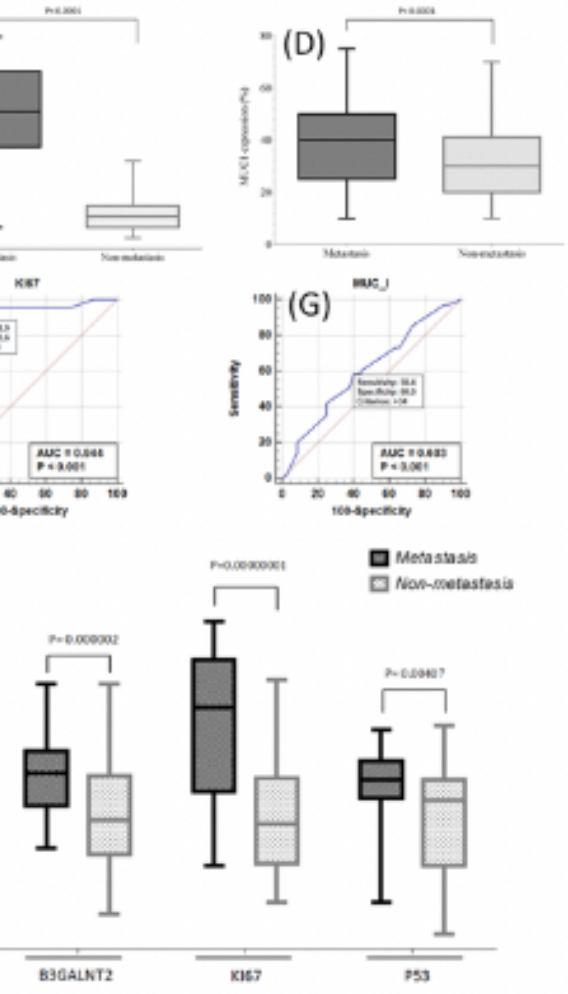

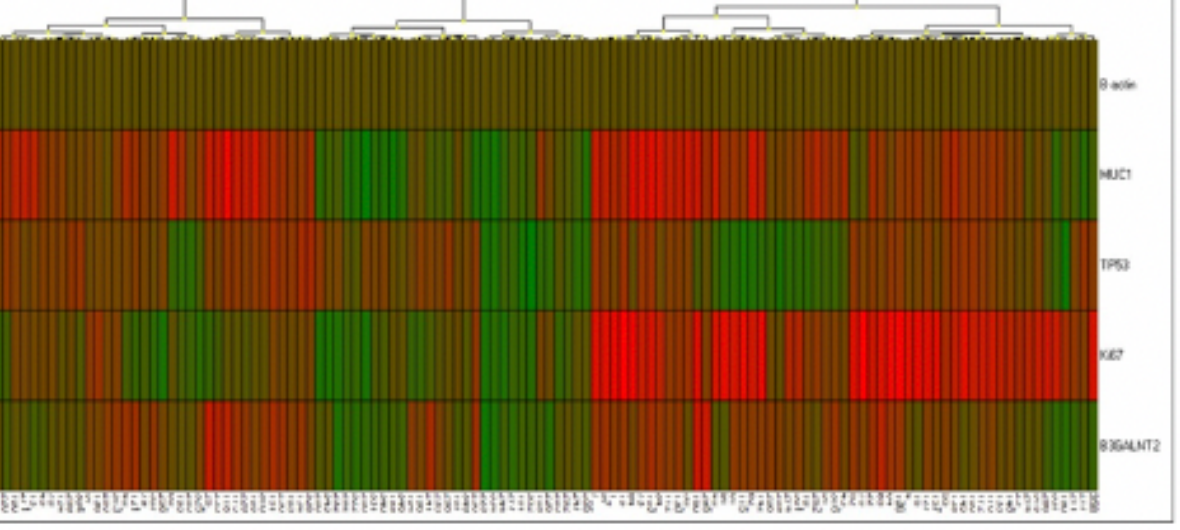

\section{Figure 5}

Representative light microscopic with H\&E staining images of colorectal cancer (CRC) stage III with metastasis (A1) and non-metastasis (A2). Immunohistochemical reactions of the CRC stage III tissues, with high (A3) and low (A4) Ki67, high (A5) and low (A6) P53, high (A7) and low (A8) MUC1 expression/labelling index with/without metastasis. Mean values of protein expression of P53 (B), Ki67 (C) and MUC1 (D).

Comparative ROC analysis showing the percent of non-metastatic and metastatic CRC patients expressing P53 (E), Ki67 (F) and MUC1 (G) along with Western blot analyses of B3GALNT2 with CL-based image [insert] (H). Comparative qPCR results of MUC1, B3GALNT2, Ki67 and P53 mRNA expression in metastatic and non- 
metastatic CRC tissues (I, $n=60$, with various $p$ values done with t-test). Comparison of full heat-map between Ki67 and TP53 genes in CRC data showing the correlation of the mRNA expressions of MUC1, B3GALNT2, Ki67 and P53 with metastasis subtypes (J).
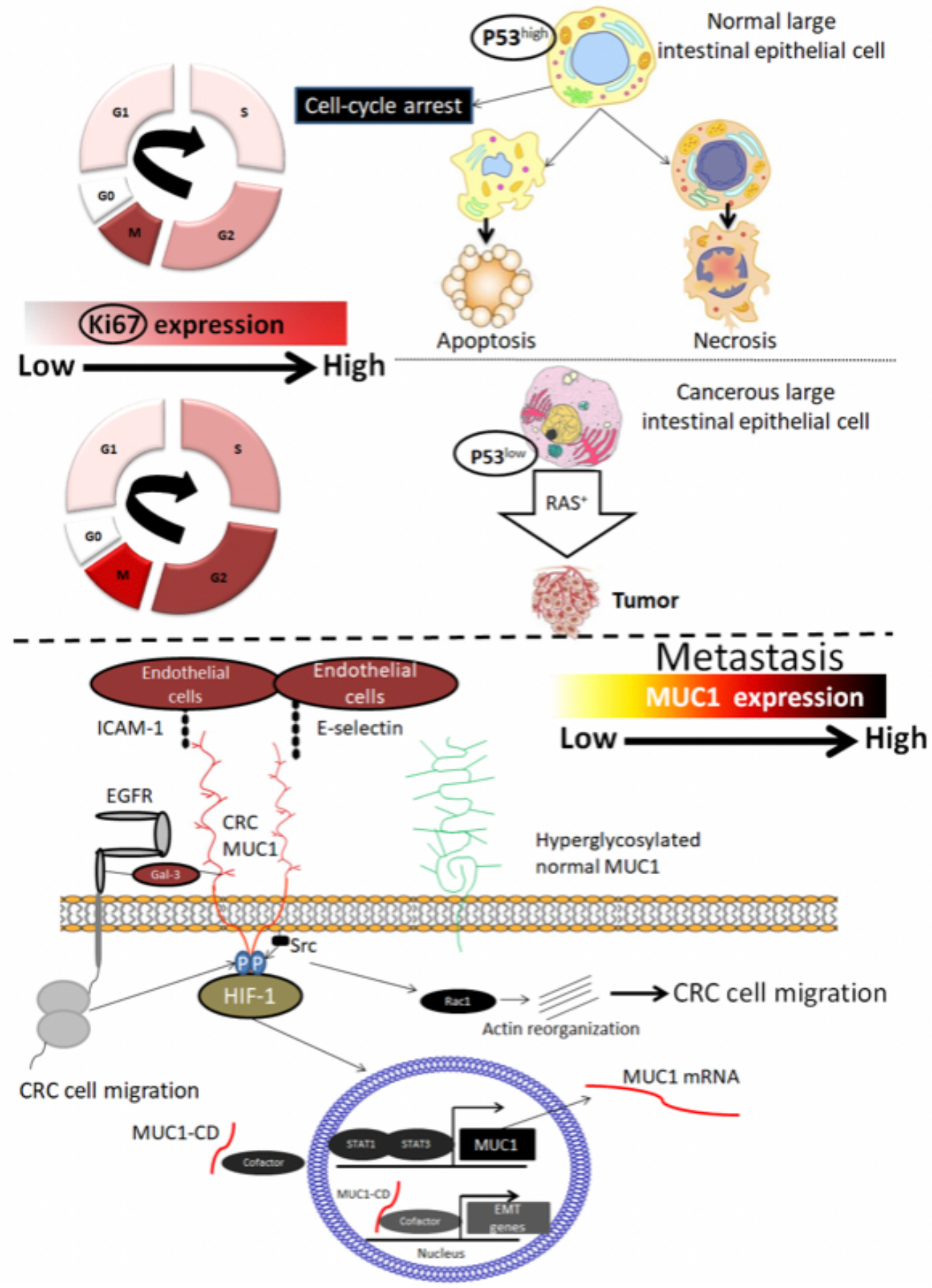

\section{Figure 6}

Schematic diagram depicting how noticeable P53low, Ki67high B3GALNT2high, MUC1high, mRNA/protein expression levels are involve in cell cycle/proliferation/spread. As such, the mRNA/protein levels of Ki67, B3GALNT2 and MUC1, but not P53, strongly correlated with CRC metastasis, observed herein; though Ki-67 
is present in all, but not resting or the $\mathrm{G} 0$ phase, of cell cycle. The intensity of Ki-67 expression in each phase of cell cycle, nonetheless, remains elusive. Though the intensity of mRNA expression of Ki-67 and P53 increases/changes, nevertheless the protein levels of those molecules could be evaluated for future prospective, and $\mathrm{Ki}-67$ protein accumulation along with its mRNA worth further analyses. Compared to noncancerous/normal colorectal cells, MUC1 undergoes post-modification (glycosylation) changes in CRC cells and promotes metastasis. Cell-surface disruption, including binding of MUC1 to E-selectin and ICAM-1, induces cancer cells to enter the blood stream. MUC1 cytoplasmic fraction is phosphorylated by EGFR and Src. Src phosphorylation can increase Rac1 activity, skeletal alteration and cellular motility. EGFR phosphorylation by cell motility, and interaction with HIF1-a. PDGF-A transcription has a positive effect on $\beta$ catenin transcriptional activity. The cytoplasmic domain of MUC1 interacts with transcription factors, such as $\beta$-catenin, p120-catenin and the estrogen receptor $\beta$, causing nuclear translocation of MUC1. Epithelial stimuli and expression are regulated by mesenchymal transition genes (EMTs), and MUC1 expression is regulated following STAT1/STAT3 binding to MUC1 and increase the production of MUC1 and thus metastasis. 